\title{
MANAJEMEN PENGEMBANGAN SDM PADA LEMBAGA PENDIDIKAN ISLAM
}

Oleh: Muhamad Priyatna*

\begin{abstract}
Abstrak
Suatu organisasi pasti memiliki cita-cita yang ingin diraih. Tujuan-tersebut diraih dengan mendayagunakan sumber daya yang ada. Dan di antara sumber daya yang paling penting adalah SDM (sumber daya manusia). Karena untuk menjadikan pendidikan berkualitas, terutama dalam hal ini adalah lembaga pendidikan, maka sumber daya manusianya harus berkualitas juga.

Sumber daya manusia merupakan unsur yang sangat vital dalam setiap organisasi, karena faktor sumber daya manusia sangat dominan dalam proses kerja organisasi, maka untuk mencapai tujuan organisasi perlu diadakan pengembangan sumber daya manusia yang dilakukan untuk meningkatkan kinerja, keterampilan, prilaku serta pengetahuan pegawai. Disamping itu, perubahan yang terjadi seiring modernisasi baik dalam lingkup organisasi maupun di luar organisasi menuntut untuk pengembangan sumber daya manusia, sehingga sebagai investasi dalam organisasi, sdm memegang peranan penting terhadap pertumbuhan suatu bangsa. Untuk itu sebagai sumber daya utama organisasi, perhatian penuh terhadap sumber daya manusia suatu keniscayaan, karena kondisi lingkungan yang dinamis, penempatan pegawai, tidak selalu menyebabkan keberhasilan, kondisi lingkungan yang cenderung berubah mengharuskan organisasi secara kontinyu melakukan penyesuaian dan pengembangan sumber daya manusia sesuai kebutuhan organisasi.
\end{abstract}

\section{A. Arti Manajemen}

Sebelum membahas Manajemen Pengembangan SDM, ada baiknya dipaparkan terlebih dahulu pengertian manjemen secara umum. Hal ini dimaksudkan untuk mengenal terlebih dahulu apa yang disebut dengan manajemen, yang kemudian akan disandingkan dengan kata sumber daya manusia.

Secara etimologi, kata manajemen berasal dari kata to manage yang artinya mengatur. Istilah manajemen telah diartikan oleh berbagai pihak dengan perspektif yang berbeda, misalnya administrasi, pengurusan, ketatalaksanaan, pengelolaan, pembinaan, kepemimpinan, pemimpin, ketatapengurusan, dan sebagainya. Dalam Webster's New Coolagiate Dictionary, kata manage dijelaskan dari “manus"atau tangan (hand). Kata manage dalam kamus bermakna membimbing dan mengawasi, mengurus perniagaan atau urusan-urusan, mencapai tujuan tertentu. ${ }^{1}$

Adapun secara terminologi, manajemen merupakan istilah yang digunakan untuk menerjemahkan kata management. Istilah yang digunakan

* Dosen Tetap STAI Al Hidayah Bogor pada Program Studi Pendidikan Agama Islam (PAI)

1 Sunhaji, Manajemen Madrasah, (Jakarta: Grafindo Litera Media. 2008), hlm. 78. 
sebelumnya adalah pengelolaan, namun belakangan ini istilah tersebut sudah jarang digunakan. Sejalan dengan berkembangnya bidang ilmu pengetahuan dan ilmu manajemen secara khusus, definisi manajemen juga mengalami perkembangan menjadi suatu uraian yang lebih spesifik dengan penyebutan fungsifungsi yang harus dilaksanakan oleh seorang manajer dalam menjalankan tugasnya. $^{2}$

T. Hani Handoko, mengutip Peter Drucker, menyatakan bahwa efesiensi ditekankan pada melalui bekerja dengan benar (doing things right) sedangkan efektif adalah melakukan pekerjaan yang benar (doing the right things). Dan yang paling penting adalah bagaimana menemukan pekerjaan yang benar untuk dilakukan dan memusatkan sumber daya dan usaha pada pekerjaan tersebut. ${ }^{3}$

George Terry memberikan definisi seperti yang dikutip oleh Hadari Nawawi bahwa manajemen adalah sebuah pencapaian tujuan dalam organisasi yang telah ditetapkan sebelumnya dengan bantuan orang lain. ${ }^{4}$ Hasibuan, mengatakan bahwa manajemen adalah ilmu atau seni mengatur pemanfaatan sumber daya manusia dan sumber-sumber lainnya secara efektif dan efesien untuk mencapai suatu tujuan tertentu. ${ }^{5}$

2 Mujahid, Manajemen Madrasah Mandiri, (Jakarta: Puslitbang, 2003), hlm. 2.

3 T. Hani Handoko, Manajemen Edisi 2, (Yogyakarta: BPFE, 1999), hlm. 7. Lihat juga Agus, Manajemen Pengantar, hlm. 3.

4 Hadari Nawawi, Manajemen Strategik: Organisasi Non Profit Bidang Pemerintahan dengan Ilustrasi di Bidang Pendidikan, (Yogyakarta: Gadjah Mada University Press, 2003), hlm. 36.

5 Hasibuan, Manajemen Sumber Daya Manusia, (Jakarta: Haji Masagung, 1994), 2. Lihat juga T. Hani Handoko, Manajemen Personalia dan
Mujahid juga mengatakan manajemen adalah seni menyelesaikan pekerjaan melalui orang lain. ${ }^{6}$ Berdasarkan definisi ini, tampak bahwa proses manajemen akan terjadi apabila kita melibatkan orang lain untuk mencapai tujuan organisasi, manajer tidak dapat melakukan sendiri tugas tersebut, tetapi melimpahkan pada orang lain atau karyawan atau bawahannya.

Manajemen mencakup kegiatankegiatan untuk mencapai tujuan, dilakukan untuk individu-individu yang menyumbangkan upayanya yang terbaik melalui tindakan-tindakan yang telah ditetapkan sebelumnya. Hal tersebut meliputi pengetahuan apa yang harus mereka lakukan, menetapkan cara bagaimana melakukannya, memahami bagaimana mereka harus melakukannya dan mengukur efektivitas dari usaha-usaha mereka. Selanjutnya, perlu ditetapkan dan dipelihara pula suatu kondisi lingkungan yang memberikan respon ekonomis, psikologis, sosial, politis, dan sumbangansumbangan teknis serta pengendaliannya. ${ }^{7}$

Dari beberapa pendapat dan keterangan definisi manajemen tersebut, maka dapat diambil kesimpulan bahwa manajemen merupakan kegiatan pimpinan dengan menggunakan segala sumber yang diperlukan untuk mencapai tujuan organisasinya sehingga dengan manajemen yang baik, diharapkan tujuan dapat tercapai dengan efektif dan efisien. ${ }^{8}$

Sumber Daya Manusia Edisi 2, (Yogyakarta: BPFE, 1998), hlm. 3.

Mujahid, Manajemen Madrasah Mandiri, hlm. 1.

Sunhaji. Manajemen Madrasah, hlm. 29.

Sunhaji. Manajemen Madrasah, hlm. 29. 


\section{B. Teori Manajemen Sumber Daya Manusia}

Manajemen sumber daya manusia adalah kebijakan dan praktek yang dibutuhkan seseorang untuk menjalankan aspek “orang” atau sumber daya manusia dari posisi seorang manajemen, meliputi perekrutan, penyaringan, pelatihan, pengimbalan, dan penilaian. $^{9}$

Menurut Sondang P. Siagian, manajemen sumber daya manusia adalah merupakan unsur yang terpenting dalam semua organisasi, keberhasilan organisasi mencapai tujuan dan berbagai sasarannya serta kemampuannya menghadapi berbagai tantangan, baik yang sifatnya eksternal maupun internal, sangat ditentukan oleh kemampuan mengelola sumber daya manusia dengan setepat-tepatnya. ${ }^{10}$ Jhon T. Seyfarth dalam bukunya yang berjudul Human Resource Management For Effective Schools, "human resources management is an essential function for creating and maintaining the conditions necessary for effective learning to occur. Hawever, the key to effective instruction is the teacher." (manajemen sumber daya manusia adalah fungsi penting dalam menciptakan dan mempertahankan kondisi yang diperlukan untuk pembelajaran yang efektif. Akan tetapi kunci bagi instruksi yang efektif adalah guru) ${ }^{11}$.

H. A. Malik Fajar pernah melontarkan statement bahwa: "Pada saat ini di dunia pendidikan kita masih

9 Gary Dessler, Sumber Daya Manusia (Human Resource Management), (New Jersey: Upper Saddle River, 1997), hlm. 2.

10 Sondang P. Siagian, Manajemen Sumber Daya Manusia, (Jakarta: Bumi Aksara, 2003), hlm. 40.

11 John T. Seyfarth, Human Resources management For Effective School, (Virginia Commonwealth University: Allyn and Bacon, 1996), hlm. 3. kekurangan guru, kalau tenaga pengajar banyak, tetapi tenaga guru masih sangat langka." Ini mengandung makna bahwa seorang guru dituntut untuk komitmen terhadap profesionalisme dalam mengemban tugasnya. Seseorang dikatakan profesional, bilamana pada dirinya melekat sikap dedikatif yang tinggi terhadap tugasnya, sikap komitmen terhadap mutu proses dan hasil kerja, serta sikap continous improvement, yakni selalu berusaha memperbaiki dan memperbaharui model-model atau cara kerjanya yang sesuai dengan tuntutan zamannya, yang dilandasi oleh kesadaran yang tinggi bahwa tugas mendidik adalah tugas menyiapkan generasi penerus yang akan hidup pada zamannya di masa depan. ${ }^{12}$

Medley mengemukakan asumsi tentang guru dalam pengembangannya yaitu: pertama, asumsi sukses guru tergantung pada kepribadianya; kedua, asumsi sukses guru tergantung pada penguasaan metode; ketiga, asumsi sukses guru tergantung pada frekuensi dan intensitas aktivitas interaktif guru dengan siswa; dan keempat, asumsi bahwa apa pun dasar dan alasannya penampilan gurulah yang terpenting sebagai tanda memiliki wawasan, ada indikator menguasai materi, indikator menguasai strategi belajar mengajar, dan lainnya. ${ }^{13}$ Jadi pada intinya bahwa SDM memainkan suatu peran terpadu dalam perubahan-perubahan untuk menuju kepada lembaga pendidikan yang berkualitas.

12 Muhaimin, Wacana Pengembangan Pendidikan Islam, (Pustaka pelajar, 2003), hlm. 210.

13 Muhaimin, Wacana Pengembangan Pendidikan Islam, hlm. 214. 
Ada banyak teori untuk mengelola sumber daya manusia di dalam organisasi. Hal ini tergantung dari tujuan dan sasaran organisasi itu. Bervariannya cara dan metode yang digunakan untuk mengelola sumber daya manusia ini karena terdapatnya asumsi tentang sifat dasar manusia. Akan tetapi, apa pun bentuk manajemen sumber daya manusia yang digunakan oleh suatu organisasi, yang pertama-tama harus disadari oleh organisasi tersebut adalah manusia merupakan aset termahal dan terpenting dari organisasi, sebab eksistensi sebuah organisasi ditentukan oleh manusiamanusia yang mendukungnya.

Pada perkembangan awal, manusia diperlakukan sebagai alat. Manusia (pekerja) sama nilainya dengan alat-alat produksi lainnya untuk mencapai hasil yang maksimal. Dalam kerangka ini, perlakuan terhadap manusia adalah sama dengan perlakuan terhadap mesin atau produksi lainnya. Proses dehumanisasi berlangsung terus, bahkan juga di abad kita yang serba komputer dan teknologi canggih ini. Padahal kalau dikaji lebih mendalam kunci keberhasilan apa pun bukan pertama terletak pada manusia yang berada di balik alat-alat ataupun sumber-sumber daya lainnya. ${ }^{14}$ Namun dalam perkembangan selanjutnya, organisasi atau manager perusahan menyadari betapa pentingnya SDM, sehingga tidak lagi menganggap manusia sebagai alat atau mesin produksi.

Karena itu, pola pemakaian manajemen yang berorientasikan pada semua pihak yang berkepentingan semakin relavanlah menempatkan manusia sebagai peran sentral dalam manajemen organisasi

14 Eris Yustiono, Pengembangan SDM (Bagian Pertama), hlm. 33. atau perusahaan. Metode-metode menginstrumenkan (menganggap benda atau alat) sumber daya manusia dalam kegiatan organisasi tidak dapat dipertanggungjawabkan lagi. Sumber daya manusia perlu dikelola dengan maksimal untuk mengoptimalkan keluaran (output) yang baik dan berkualitas serta memiliki nilai. Unsur manusia harus menjadi dasar pijakan dan pertimbangan utama dari manajemen. $^{15}$

Manajemen Sumber Daya Manusia (MSDM) mempunyai dua posisi penting, yaitu (a) merupakan bagian penting dari organisasi yang berkaitan dengan dimensi manusia, (b) merupakan fungsi staff atau pendukung dalam organisasi. Kegunaan MSDM adalah untuk selalu ditingkatkan keterampilannya, dimotivasi untuk berprestasi lebih baik, diusahakan untuk tetap tinggi komitmennya dan tetap betah. ${ }^{16}$

Adapun empat fungsi MSDM adalah: (a) penerimaan karyawan secara selektif dengan perencanaan yang matang, (b) training dan pengembangan untuk mempersiapkan SDM bekerja, mereka perlu mengetahui aturan-aturan organisasi, kebiasaan, dan tujuan organisasi, (c) motivation, yaitu merangsang SDM untuk berkarya. Hal ini berhubungan dengan aspek kemanusiaan yang kompleks, (d) maintenance, untuk membangun komitmen karyawan sehingga mereka betah dan bertahan dalam sebuah organisasi. Fungsi pokok manajemen SDM dilakasanakan dalam bingkai atau sangat dipengaruhi oleh dinamika lingkungan, peraturan-

15 Eris Yustiono, Pengembangan SDM (Bagian Pertama), 33.

16 Eris Yustiono, Pengembangan SDM (Bagian Pertama), hlm. 34-35. 
peraturan pemerintah, teori manajemen dan lingkungan global. ${ }^{17}$

\section{Tujuan Pengembangan Sumber Daya Manusia}

Secara umum tujuan pengembangan sumber daya manusia adalah untuk memastikan bahwa organisasi mempunyai orang-orang yang berkualitas untuk mencapai tujuan organisasi untuk meningkatkan kinerja dan pertumbuhan. ${ }^{18}$

Tujuan tersebut di atas dapat dicapai dengan memastikan bahwa setiap orang dalam organisasi mempunyai pengetahuan dan keahlian dalam mencapai tingkat kemampuan yang dibutuhkan untuk melaksanakan pekerjaan mereka secara efektif. Selain itu perlu pula diperhatikan bahwa dalam upaya pengembangan sumber daya manusia ini, kinerja individual dan kelompok adalah subjek untuk peningkatan yang berkelanjutan dan bahwa orang-orang dalam organisasi dikembangkan dalam cara yang sesuai untuk memaksimalkan potensi serta promosi mereka.

Beberapa tujuan pengembangan sumber daya manusia adalah sebagai berikut: ${ }^{19}$

1. Meningkatkan produktivitas kerja.

2. Mencapai efisiensi.

3. Meminimalisir kerusakan.

17 Eris Yustiono, Pengembangan SDM (Bagian Pertama), hlm. 35.

18 M. Armstrong Personnel Management Practice, Fourth Edition (London: Kogan Page limited, 1991), hlm. 507.

19 Eris Yustiono, Pengembangan SDM (Bagian Pertama), lihat http://www.stialanbandung.ac.id/index.php?opti on=com_content $\&$ view $=$ article $\& i d=389$ : pengembangan-sdm-bagian-pertama\& catid $=12$ : artikel\&Itemid $=85$
4. Mengurangi kecelakaan.

5. Meningkatkan pelayanan.

6. Memelihara moral pegawai.

7. Meningkatan peluang karier.

8. Meningkatkan kemampuan konseptual.

9. Meningkatkan kepemimpinan.

10. Peningkatan balas jasa.

11. Peningkatan pelayanan kepada konsumen.

Dengan meningkatnya kemampuan pegawai, baik konseptual, maupun teknikal, maka upaya pemberian pelayanan kepada konsumen pun akan berjalan lebih baik pula.

\section{Konsep Pengembangan Sumber Daya Manusia Pendidikan}

Jika disandingkan dengan kata manajemen, maka secara sederhana, manajemen sumber daya manusia diartikan sebagai kegiatan perencanaan, pengorganisasian, pengarahan dan pengawasan kegiatan-kegiatan, pengadaan, pengembangan, pemberian kompensasi, pengintegrasian, pemeliharaan dan pelepasan sumber daya manusia agar tercapai berbagai tujuan individu, organisasi, dan masyarakat.

Menurut Silalahi, pengembangan sumber daya manusia antara lain didasarkan atas asumsi bahwa manusia mempunyai potensi sumber daya yang tidak dapat ditentukan batas-batasnya. Dalam hal ini, manusia juga merupakan unsur terpenting yaitu sebagai subjek yang melaksanakan dan menggerakkan sumber daya lainnya kepada tujuan yang hendak dicapai. Hasibuan menjelaskan, bahwa pengembangan sumber daya manusia juga merupakan suatu usaha untuk meningkatkan kemampuan teknis, teoritis atau konseptual dan sikap 
personal sesuai dengan kebutuhan pekerjaan atau jabatan melalui pendidikan dan pelatihan. ${ }^{20}$

Pengembangan sumber daya manusia bagi pegawai adalah suatu proses belajar dan berlatih secara sistematis untuk meningkatkan kompetensi dan kinerja mereka dalam pekerjaannya sekarang dan menyiapkan diri untuk peran dan tanggung jawab yang akan datang. $^{21}$

Pengembangan sumber daya manusia hendaknya didasarkan atas kebutuhan individu dan organisasi atau lem-baga serta direncanakan secara cermat dan sistematis dengan menggunakan metode ilmiah tertentu sehingga mencapai tujuan organisasi

Nasir Usman menyatakan, bahwa Sumber daya manusia yang berkualitas dikembangkan melalui banyak cara antara lain:

1. Melalui pendidikan dasar sampai dengan perguruan tinggi

2. Melalui program pendidikan dan pelatihan yang sistematik maupuninformal ditempat kerja.

3. Pengembangan diri sendiri, atas inisiatif sendiri berupaya memperoleh pengetahuan dan keterampilan. $^{22}$

Kegiatan inti pengembangan kualitas sumber daya manusia menurut Suke Silverius, berada pada proses pembelajaran dikelas yang kondusif. Penerapan desentralisasi pendidikan ditingkat kelas dalam pengembangan

20 Sunhaji. Manajemen Madrasah, hlm. 29.

21 Achmad S. Ruky, Sumber Daya Manusia Berkualitas (Jakarta: PT. Gramedia Pustaka Utama, 2006), hlm. 227.

22 Nasir Usman, Manajemen Peningkatan Mutu Kinerja Guru, Konsep, Teori, dan Model (Bandung: Citapustaka Media Perintis, 2012), hlm. 17 kualitas sumber daya manusia, antara, lain sebagai berikut :

1. Guru dan siswa saling mengajar dan saling belajar

2. Guru dan siswa saling berfikir dan memikirkan

3. Guru dan siswa saling bicara dan saling mendengarkan

4. Guru dan siswa saling mengatur dan diatur

5. Guru dan siswa bersama-sama memilih dari sekian alternatif yang perlu dilaksanakan bersama-sama untuk mewujudkan pendidikan di kelasnya pada khususnya di sekolah pada umumnya. ${ }^{23}$

Pengembangan sumber daya manusia ini dirancang untuk meningkatkan efektivitas manajer secara keseluruhan dalam jabatan yang sekarang dan untuk menyiapkan mereka untuk bertanggung jawab yang lebih besar bila mereka dipromosikan. Program pengembangan sumber daya manusia telah mendapat perhatian pada akhir-akhir ini karena makin rumitnya tuntutan terhadap pekerja. Jika kita membiarkan pengalaman saja untuk melatih pekerja merupakan suatu proses yang terlalu banyak memakan waktu serta tidak dapat diandalkan. ${ }^{24}$

\section{E. Proses Pengembangan Sumber Daya Manusia Pendidikan}

Untuk pengembangan sumber daya manusia harus dimulai dari rencanarencana sumber daya manusia organisasi karena rencana ini menganalisa,

23 Taufik Rahman, Manajemen Sumber Daya Manusia, (Bandung: Citapustaka Media Perintis, 2009), hlm. 49.

24 Taufik Rahman, Manajemen Sumber Daya Manusia, hlm. 49. 
meramalkan atau memprediksi dan menyebutkan kebutuhan organisasi untuk sumber daya manusia pada saat ini dan yang akan datang, selain itu perencanaan sumber daya manusia gerakan orang-orang dalam organisasi yang disebabkan oleh pensiun, promosi, dan pemindahan tugas. Selain itu perencanaan sumber daya manusia menyebutkan kapabilitas yang dibutuhkan oleh organisasi tersebut dimasa yang akan datang guna memenuhi kebutuhan tersebut.

Proses pengembangan sumber daya manusia, pertama-tama dilakukan melalui penetapan rencana sumber daya manusia, dengan menyebutkan kapabilitas para individu yang dibutuhkan lebih dahulu. Kapabilitas tersebut tentu saja dapat mempengaruhi perencanaan. Kemampuan tertentu dapat mempengaruhi keputusan tentang promosi dan proses suksesi di dalam organisasi tersebut. Keputusan itu mempengaruhi dan dipengaruhi oleh keputusan penilaian atas kebutuhan pengembangan dalam organisasi. Dua kategori perencanaan pengembangan yang merupakan hasil dari penilaian kebutuhan ini organisasi dan individual. Terakhir, keberhasilan proses pengembangan harus dievaluasi dan dilakukan perubahan sesuai kebutuhan. ${ }^{25}$

Nasir Usman menyatakan bahwa, pengembangan guru dalam lembaga pendidikan secara efektif dapat dilaksanakan melalui strategi berikut: ${ }^{26}$

1. Membuat desain perencenaan terhadap kebutuhan pengembangn guru.

25 Robert L. Mathius - John H. Jackson, Human Resource Manogement, Manajemen Sumber Daya Manusia terj. Diana Angelica (Jakarta: Salemba Empat, 2004), hlm. 352.

26 Nasir Usman, Manajemen Peningkatan Mutu Kerja Guru, hlm. 110.
2. Membuat program pengembangan guru

3. Mengimplimentasikan program pengembangan, dan

4. Mengadakan evaluasi terhadap pengembangan guru.

Karena itu, pengembangan guru merupakan suatu usaha kemampuan teknis, teoritis-konseptual, dan sikap guru sesuai dengan kebutuhan pekerjaan atau jabatan yang dilakukan melalui pendidikan dan latihan. Lebih lanjut Castetter mengemukakan bahwa, proses pengembangan sumber daya manusia (guru) terdiri dari langkah-langkah sebagai berikut: ${ }^{27}$

Strategi yang harus dilakukan dalam proses pengembangan sumber daya manusia pada suatu organisasi akan memberikan panduan kepada pemegang jabatan (pimpinan) dalam melakukan pengembangan sumber daya manusia (guru) yang efektif, dan dapat ditempuhmelalui empat fase penting, yaitu: (1) fase diagnotik, (2) fase desain, (3) fase implementasi/operasi, dan (4) fase evaluasi.

1. Fase diagnostik adalah mendiagnosis fase kebutuhan pengembangan berkaitan dengan kebutuhan individu kebutuhan kelompok, dan kebutuhan organisasi. Rencana pengembangan tersebut harus menjawab kebutuhan organisasi secara komperhensif yang bertujuan untuk meningkatkan kemampuan khusus ditandai dengan pengetahuan spesifik dan keahlian tertentu bagi individu yang memegang jabatan. Potensi yang dimiliki menjadi bekal

27 Nasir Usman, Manajemen Peningkatan Mutu Kerja Guru, hlm. 110. 
untuk dikembangkan dan semuanya harus diawali dengan diagnosis untuk kepentingan rencana penembangan sumber daya manusia.

2. Fase desain adalah merancang rencana pengembangan berdasarkan kepada: (1) masalah-masalah organisasi dan kebutuhan program pengembangan sebagai pendahuluan, (2) mendeskripsi tujuan khusus danseleksi tujuan khusus dan seleksi tujuan berdasarkan dampak, (3) menentukan pihak-pihak yang ikut berpartisipasi, (4) merencanakan pengganti dengan melakukan identifikasi dan pengembangan sebagai bagian penting. (5) menetapkan kelender untuk mencapai tujuan, (6) merancang kebutuhan individu dan kebutuhan kelompok dalam berbagai kegiatan, (7) merekrut peserta, (8) menyususn deskripsi waktu, prosedur dan evaluasi, dan (9) menetapkan jadwal monitoring.

3. Fase implimentasi/operasi adalah melaksanakan program pengembangan sesuai dengan rencana yang membutuhkan dukungan berbagai pihak untuk menilai relevansi program yang dipilih dan dilaksanakan pada kesempatan tersebut, dan melakukan koordinasi terutama dalam rangka mewujudkan tenaga profesional.

4. Fase evaluasi adalah mengarahkan kegiatan evaluasi untuk melihat kinerja administrasi dan rasional metode/teknik yang digunakan selama program pengembangan diimplementasikan. Pada dasarnya untuk mengetahui bagaimana implementasi pengembangan dilihat dari jalur yang tidak menyimpang, dari yang direncanakan.

Jadi keempat fase tersebut hendaknya diimplementasikan oleh pemegang jabatan (pimpinan) dengan menentukan posisi jabatan yang ditetapkan sebagai lokasi pengembangan. Setelah posisi jabatan disetujui menjadi kebutuhan yang diprioritas untuk dijadikan kebijakan dalam rangka mengisi formasi sekaligus memperoleh tenaga-tenaga terampil dan cakap melaksanakan tugas, maka dianalisis kebutuhan. $^{28}$

Namun menurut Eris Yustiono, sebelum proses pengembangan sumber daya manusia ini dilaksanakan, maka ada dua pertanyaan pokok yang harus dijawab, yaitu:

1. Apakah kebutuhan pelatihan kita?

2. Apa yang ingin kita penuhi melalui upaya pengembangan sumber daya manusia?

Setelah menentukan tujuan proses pengembangan sumber daya manusia, maka manajemen dapat menentukan metode-metode yang cocok dan media yang tepat untuk memenuhi tujuan yang telah ditentukan tersebut. Pada dasarnya banyak sekali metode dan media yang dapat digunakan, namun dalam prakteknya, pemilihan metode tersebut tergantung pada tujuan pengembangan sumber daya manusia. Secara umum, pengembangan sumber daya manusia harus selalu dievaluasi secara terus-menerus dalam rangka memfasilitasi perubahan dan memenuhi tujuan organisasi. ${ }^{29}$

\footnotetext{
28 Nasir Usman, Manajemen Peningkatan Mutu, hlm. 111.

29 Eris Yustiono, Pengembangan SDM, hlm. 5.
} 
Dalam bentuk bagan, proses/tahap pengembangan sumber daya manusia dapat digambarkan sebagai berikut:

Proses/Tahap Program Pelatihan dan Pengembangan SDM

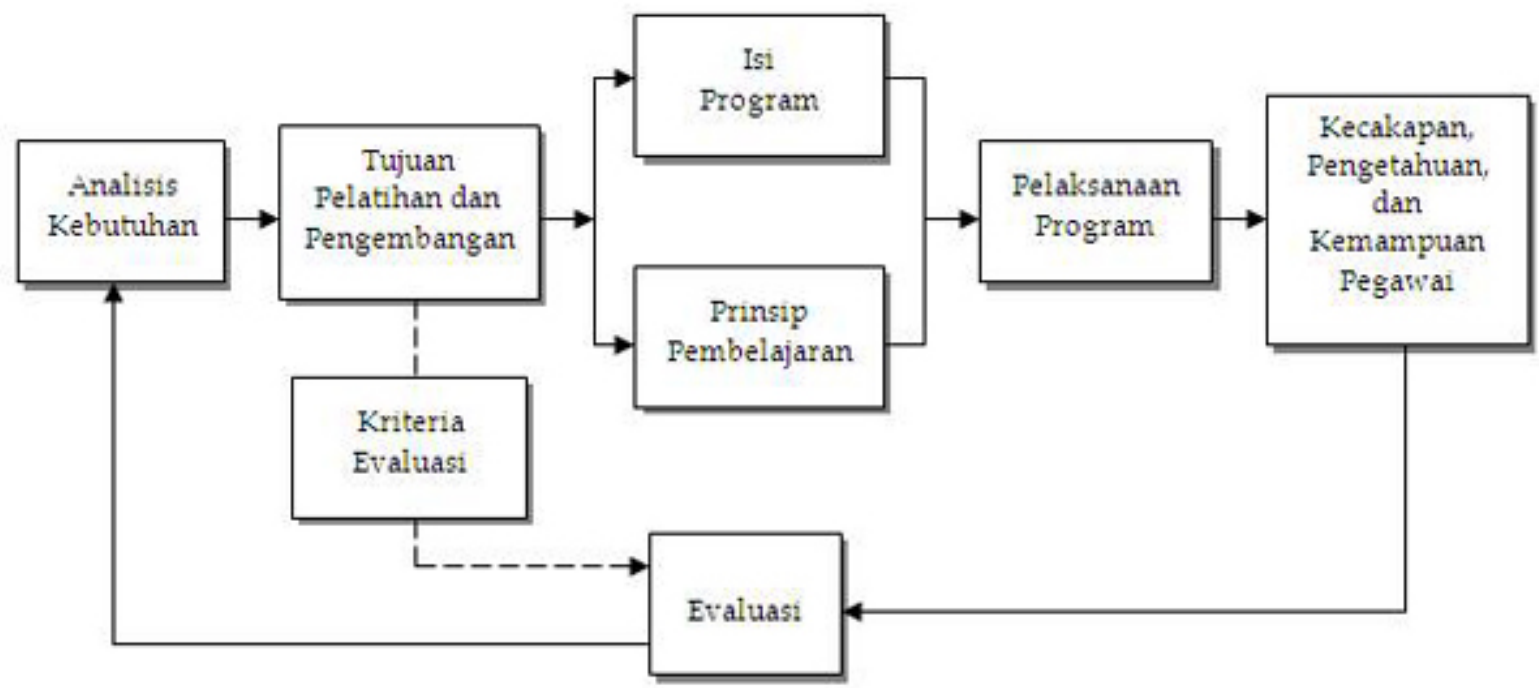

Sumber: Diadaptasi dari Werther and Davis (1996:2S7)

\section{Menentukan Kebutuhan}

Seperti tergambar dalam bagan, bahwa langkah pertama dalam proses pengembangan sumber daya manusia adalah analisis kebutuhan Pengembangan SDM yang menurut Werther and Davis: "Needs assesments diagnoses current problems and future challenges to be met through training and development". Secara bebas dapat diterjemahkan sebagai berikut: Analisis kebutuhan yaitu suatu proses mendiagnosa masalah-masalah yang terjadi pada saat ini dan tantangan masa depan yang akan diantisipasi melalui pelatihan dan pengembangan. Penentuan kebutuhan ini bukan karena organisasi/perusahaan lain melakukan hal yang sama, akan tetapi harus benar-benar dilandasi kebutuhan organisasi. Atau dengan kata lain prinsip pertama yang harus dipenuhi adalah mengetahui apa yang dibutuhkan. Analisis kebutuhan (needs assessment) adalah suatu penentuan kebutuhan pelatihan yang sistematis yang terdiri dari tiga jenis analisis. Analisisanalisis tersebut diperlukan dalam menentukan tujuan pelatihan. Ketiga analisis tersebut adalah analisis organisasional (organisational analysis), analisis pekerjaan (job analysis), dan analisis individual (individual analysis). ${ }^{30}$

Analisis organisasional adalah suatu analisis yang berusaha untuk menjawab pertanyaan mengenai dimana tempat atau bagian mana dari organisasi yang paling membutuhkan pelatihan dan faktor-faktor apa yang mungkin mempengaruhi pelatihan. Dengan kata lain analisa organisasional berarti melihat keseluruhan organisasi dalam menentukan dimana

30 Eris Yustiono, Pengembangan SDM, hlm. 5. 
program-program pelatihan, pendidikan, dan pengembangan akan diselenggarakan. Dalam analisa ini, tujuan-tujuan strategis organisasi juga rencana-rencana organisasi, perlu dipertimbangkan dengan seksama. Biasanya analisa ini juga dipikirkan pada waktu proses perencanaan sumber daya manusia. Untuk melakukan analisis organisasional, organisasi harus mempehatikan tujuan-tujuan organisasi, inventarisasi pegawai, dan lingkungan organisasi. Selain itu perkiraan suplai pegawai dan gap yang ada perlu mendapat perhatian. $^{31}$

Analisis pekerjaan adalah suatu analisis yang mencoba menjawab mengenai apa yang seharusnya dilatihkan sehingga pegawai dapat melakukan pekerjaannya dengan baik. Dalam melakukan analisis pekerjaan, uraian pekerjaan -yang menggambarkan pekerjaan yang harus dilakukan- dan deskripsi jabatan -yang menggambarkan kompetensi yang yang harus dimiliki dalam melakukan suatu pekerjaan- harus menjadi perhatian. Namun demikian, jika ternyata uraian pekerjaan yang ada tidak cukup sebagai sumber informasi, bila perlu diadakan wawancara terhadap para manajer dan para pegawai non-manajer (operasional) untuk mendapat saran/ masukan yang diinginkan sehubungan dengan rencana penyelenggaraan program pengembangan pegawai. ${ }^{32}$

Analisis individual adalah suatu analisis yang mencoba menjawab mengenai siapa yang memerlukan pelatihan dan jenis pelatihan apa yang dibutuhkan oleh para pegawai tersebut. dengan kata lain analisa individual

31 Eris Yustiono, Pengembangan SDM, hlm. 5.
32 Eris Yustiono, Pengembangan SDM, hlm. 6. memfokuskan diri pada pegawai yang akan diikutsertakan dalam program pengembangan pegawai. Analisa ini berkaitan dengan dua pertanyaan pokok sebagai berikut: ${ }^{33}$

1. Siapa yang perlu diikutsertakan dalam program pengembangan?

2. Jenis pengembangan pegawai apa yang dibutuhkan?

Untuk menjawab pertanyaan pertama, maka cara sederhana dengan membandingkan kinerja pegawai dengan standar yang telah ditentukan dapat digunakan. Apabila hasil perbandingan menunjukkan tidak ada gap antara standar dengan kinerja, maka program pengembangan tidak dibutuhkan. Jika ternyata kinerja pegawai di bawah standar yang diinginkan, maka upaya lebih lanjut untuk mengetahui penyebabnya perlu dilakukan.

Selain cara tersebut di atas, bermain peran, dan pusat pelatihan dapat juga digunakan dalam mengadakan analisa individual. Hasil program perencanaan karir juga dapat digunakan sebagaimana pusat pelatihan.

\section{Menetapkan Tujuan}

Penentuan tujuan yang jelas merupakan hal yang tidak dapat diindahkan. Tanpa tujuan yang jelas, maka upaya mendesain program-program pelatihan dan pengembangan merupakan suatu hal yang sulit. Selain itu adanya tujuan yang jelas akan mempermudah dalam hal pengukuran hasil yang diharapkan sekaligus mengukur keberhasilan suatu program pengembangan. ${ }^{34}$

33 Eris Yustiono, Pengembangan SDM, hlm. 6.

34 Eris Yustiono, Pengembangan SDM, hlm. 6. 
berikut:

Contoh tujuan adalah sebagai

1. Setelah mengikuti pelatihan "Excellent Service", seorang Customer Service dapat menyelesaikan formulir per-mohonan pengajuan kredit dalam waktu 10 menit setelah semua informasi diterima dari pemohon kredit.

2. Setelah mengikuti pelatihan, peserta pelatihan dapat menyusun sesuai format yang telah ditentukan.

\section{F. Pelatihan dan Pengembangan Sumber Daya Manusia Pendidikan}

Pengertian pelatihan, seperti menurut Nitisemito, Pelatihan adalah suatu kegiatan dari perusahaan yang bermaksud untuk dapat memperbaiki dan mengembangkan sikap, tingkah laku, keterampilan dan pengetahuan dari para pegawai yang sesuai dengan keinginan lembaga yang bersangkutan. ${ }^{35}$

Menurut Simamora, pelatihan adalah proses sistematik pengubahan perilaku para pekerja dalam suatu arah guna meningkatkan tujuan-tujuan organisasional. ${ }^{36}$ Armstrong, “Training is A planned process to modify attitude,knowledge or skill behavior through learning experience to achieve effectivepeformance in an activity or of activities'. ${ }^{37}$ Dari berbagai pendapat di atas maka penulis dapat menarik kesimpulan bahwa pelatihan bukanlah merupakan

\footnotetext{
35 S.A. Nitisemito Manajemen Personalia, Edisi Delapan (Jakarta: Penerbit Ghalia Indonesia, 1994), hlm. 45.

36 H. Simamora, Manajemen Sumber Daya Manusia, Edisi ke-2, (Yogyakarta: Penerbit Sekolah Tinggi Ilmu Ekonomi, YKPN, 1997), hlm. 67.

37 M. Armstrong, Personnel Management Practice, Fourth Edition (London: Kogan Page Limited, 1991), hlm. 98.
}

suatu tujuan, tetapi merupakan suatu usaha untuk meningkatkan tanggung jawab mencapai tujuan perusahaan. Pelatihan merupakan proses keterampilan kerja timbal balik yang bersifat membantu, oleh karena itu dalam pelatihan seharusnya diciptakan suatu lingkungan di mana para guru dapat memperoleh atau mempelajari sikap, kemampuan, keahlian, pengetahuan dan perilaku yang spesifik yang berkaitan dengan pekerjaan, sehingga dapat mendorong mereka untuk dapat bekerja lebih baik.

Simamora menyatakan, bahwa tujuan-tujuan utama pelatihan pada intinya dapat dikelompokkan ke dalam lima bidang:

1. Memperbaiki kinerja, kendatipun pelatihan tidak dapat memecahkan semua masalah kinerja yang tidak efektif, program pelatihan dan pengembangan yang sehat kerap berfaedah dalam meminimalkan masalah-masalah ini.

2. Memutakhirkan keahlian para guru sejalan dengan kemajuan teknologi.

3. Melalui pelatihan, pelatih (trainer) memastikan bahwa guru dapat secara efektif menggunakan teknologiteknologi baru. Perubahan teknologi, pada gilirannya, berarti bahwa pekerjaan-pekerjaan sering berubah dan keahlian serta kemampuan guru mestilah dimuktakhirkan melalui pelatihan sehingga kemajuan teknologi tersebut secara sukses dapat diintegrasikan ke dalam organisasi.

4. Mengurangi waktu belajar bagi guru baru supaya menjadi kompeten dalam pekerjaan. Sering seorang guru baru tidak memiliki keahlian-keahlian dan kemampuan yang dibutuhkan untuk 
menjadi “job competent," yaitu mampu mencapai output dan standar kualitas yang diharapkan.

5. Membantu memecahkan permasalahan operasional. Meskipun persoalanpersoalan organisasional menyerang dari berbagai penjuru, pelatihan adalah sebagai salah satu cara terpenting guna memecahkan banyak dilema yang harus dihadapi oleh manajer.

6. Mempersiapkan guru untuk promosi. Salah satu cara untuk menarik, menahan, dan memotivasi guru adalah melalui program pengembangan karir yang sistematik. ${ }^{38}$

Mengembangkan kemampuan promosional guru adalah konsisten dengan kebijakan personalia untuk promosi dari dalam pelatihan adalah unsur kunci dalam sistem pengembangan karir. Organisasiorganisasi yang gagal menyediakan pelatihan untuk memobilitas vertikal akan kehilangan guru yang beroirentasipencapaian (achievement oriented) yang merasa frustasi karena tidak adanya kesempatan untuk promosi dan akhirnya memilih keluar dari perusahaan dan mencari perusahaan lain yang menyediakan pelatihan bagi kemajuan karir mereka.

Mengorientasikan guru terhadap organisasi. Selama beberapa hari pertama pada pekerjaan, guru baru membentuk kesan pertama mereka terhadap organisasi dan tim manajemen. Kesan ini dapat meliputi dari kesan yang menyenangkan sampai yang tidak mengenakkan, dan dapat mempengaruhi kepuasan kerja dan produktivitas keseluruhan guru.

38 Simamora, Manajemen, hlm. 87.
Karena alasan inilah, beberapa pelaksana orientasi melakukan upaya bersama supaya secara benar mengorientasikan guru-guru baru terhadap organisasi dan pekerjaan. Memenuhi kebutuhan-kebutuhan pertumbuhan pribadi. Pelatihan dan pengembangan dapat memainkan peran ganda dengan menyediakan aktivitas-aktivitas yang membuahkan efektifitas organisasional yang lebih besar dan meningkatkan pertumbuhan pribadi bagi semua guru.

Dari pendapat di atas mengenai tujuan pelatihan maka dapat disimpulkan bahwa adanya pelatihan diharapkan dapat mengembangkan guru sesuai dengan kompetensinya, dapat menggunakan keahliannya sesuai dengan perubahan teknologi, guru akan lebih berorientasi pada pengembangan kegiatan belajar mengajar, meningkatkan kinerja guru dan untuk pengembangan karir, sehingga adanya pelatihan diharapkan akan dapat meningkatkan pertumbuhan pribadi setiap guru.

Pelatihan merupakan proses keterampilan kerja timbal balik yang bersifat membantu. Karena itu, dalam pelatihan seharusnya diciptakan suatu lingkungan di mana para peserta pelatihan dapat memperoleh atau mempelajari sikap, kemampuan, keahlian, pengetahuan dan perilaku yang spesifik yang berkaitan dengan pekerjaan, sehingga dapat mendorong mereka untuk dapat bekerja lebih baik.

Latihan adalah suatu kegiatan untuk memperbaiki kemampuan kerja seseorang, sedangkan pendidikan merupakan suatu kegiatan untuk meningkatkan pengetahuan umum seseorang, termasuk di dalamnya peningkatan penguasaan teori dan 
keterampilan membuat keputusan yang menyangkut kegiatan mencapai tujuan. ${ }^{39}$ Dapat disimpulkan bahwa pengertian pengembangan memiliki ruang lingkup yang lebih luas dibandingkan dengan pelatihan dan pendidikan. Karena latihan dan pendidikan hanya meningkatkan dua aspek saja yaitu kemampuan dan pengetahuan. Sementara pengembangan mencakup tigas aspek yang terdiri dari: pengetahuan, kecakapan/ kemampuan, dan sikap. Dengan demikian kedua istilah tersebut merupakan bagian dalam pengembangan sumber daya manusia.

Penyamarataan arti bagi istilah latihan dan pengembangan mungkin bisa dimaklumi mengingat kedua istilah tersebut memiliki tujuan yang saling mendukung yaitu :

a. Latihan dan pengembangan dilakukan untuk menutup gap antara kecakapan atau kemampuan guru dengan permintaan jabatan.

b. Program-program ini dapat meningkatkan efisiensi dan ekfektifitas kerja guru dalam mencapai sasaran-sasaran kerja yang telah dicapai.

c. Dapat membantu tenaga pengajar dalam menghindarkan diri dari keusangan dan melaksanakan pekerjaan dengan lebih baik. ${ }^{40}$

Selain memiliki tujuan yang sama, kedua istilah ini juga memiliki fungsi yang hampir sama dan cenderung saling

39 Heidjrachman Ranupandojo dan Suad Husnan, Manajemen Personalia, Edisi Ketiga (Yogyakarta: Pelajar, 1986), hlm. 77.

40 Hani T. Handoko, Manajemen Personalia dan Sumber Daya Manusia, Edisi 2, BPFE (Yogyakarta: Pustaka Pelajar, 1993), hlm. 103. mendukung, namun letak perbedaannya yaitu pada sasaran akhirnya. Program pelatihan diarahkan untuk memelihara dan memperbaiki prestasi kerja saat ini, sementara pengembangan dimaksudkan untuk mengembangkan keterampilan untuk pekerjaan masa depan. Baik manajer maupun bukan manajer akan terbantu dengan program pelatihan dan pengembangan, meskipun pengalaman yang didapat berbeda-beda.

Namun selanjutnya di dalam pembahasan ini akan dipakai istilah pelatihan, dan bila disebutkan istilah latihan, maka istilah itu merupakan bagian dari proses pengembangan. Maka jelaslah pelatihan merupakan kegiatan yang harus dilaksanakan oleh lembaga pendidikan dan latihan (diklat) agar pengetahuan, kemampuan dan keterampilan guru, baik fungsional maupun manajerial, dapat bertambah sehingga mereka dapat melaksanakan tugas sesuai dengan tuntutan pekerjaannya. Dengan adanya kegiatan pelatihan, maka lembaga pendidikan dapat memperbaiki dan mengatasi kekurangsempurnaan pelaksanaan tugas dan mengatasi kesenjangan antara kemampuan dengan tuntutan pekerjaan yang biasanya dialami oleh guru.

Pelatihan yang akan dibahas selanjutnya meliputi kegiatan pengembangan pengetahuan dan keterampilan, yang memiliki arti meningkatkan kemampuan guru agar mereka lebih mengenal dan memahami seluk pelaksanaan pekerjaan secara lebih mendalam, memahami perkembangan dan sasaran yang akan dicapai lembaga pendidikan, senantiasa menghidupkan kerjasama dalam menghadapi kesulitan-kesulitan yang dihadapi lembaga pendidikan. Hal ini 
sesuai dengan yang dikemukakan oleh Ronald Nangoi bahwa: "Pendekatan yang paling efektif dan tepat yang perlu dilakukan adalah investasi sumber daya manusia (human invesment) melalui program-program pendidikan manajerial dan teknis yang ada dan relevan dengan kebutuhan organisasi. ${ }^{41}$

Pendidikan dan latihan (diklat) yang dilaksanakan di lembaga pendidikan, bila dilihat dari bentuknya dapat diklasfikasikan pada dua segi, yakni:

a. Dari segi peserta:

1) Guru yang menjabat jabatan struktural/manajer,

pengembangan ditujukan pada pemantapan keterampilan dalam penanganan tugas dan masalahmasalah strategis organisasi, sehingga berbagai segi yang berkaitan dengan kerja kepemimpinan bisa lebih efektif.

2) Guru yang menjabat jabatan fungsional, pengembangan ditujukan pada peningkatan pengetahuan dan ketrampilan teknis, khususnya proses belajar mengajar, penelitian, pengabdian, pembimbingan

sehingga performance kerja lebih baik.

b. Dari segi tahapan pendidikan dan latihan (diklat), idealnya diawali oleh pengembangan pimpinan-pimpinan puncak yang langsung berhubungan dengan guru, seperti kepala lembaga pendidikan dan pimpinan-pimpinan lain yang mendapat program pengembangan terlebih dahulu. Kemudian

41 Ronald Nangoi, Pengembangan Produksi Dan Sumber Daya Manusia, Cet. Kedua (Jakarta: Rineka Cipta, 1996), hlm. 124. pengembangan diarahkan pada person-person di bawahnya dilihat dari tingkat keorganisasian. ${ }^{42}$ Melalui tahapan model ini, prinsip-prinsip pengembangan guru dapat lebih siap untuk diimplementasikan dan diaplikasikan.

Dari format yang ditawarkan di atas, dapat dimengerti bahwa pendidikan dan latihan (diklat) merupakan tanggung jawab semua pimpinan. Kepala lembaga pendidikan sebagai pimpinan di lembaga pendidikan harus secara kontinyu memenuhi kebutuhan pengembangan bagi para guru dan mendorong mereka untuk berperan serta dalam program pendidikan dan latihan (diklat), baik di dalam maupun di luar tempat kerja.

Ada tiga aspek yang dapat diperbaiki dan dikembangkan melalui kegiatan pendidikan dan latihan (diklat), yaitu, pengetahuan, keterampilan dan sikap. Adapun pengembangan pengetahuan para guru dapat dilakukan dengan berbagai cara, di antaranya dengan:

a. Banyak membaca buku-buku, brosur, majalah dan surat kabar.

b. Banyak mendengar ceramah, siaransiaran radio/TV.

c. Sering mengikuti rapat, pertemuran, diskusi, seminar, dan lokakarya.

d. Terlibat secara aktif dalam acaraacara yang dilaksanakan sekolah.

e. Mengikuti pendidikan yang lebih tinggi dan pelatihan serta kursus tambahan.

42 T. Ray Fortunato dan Geneva D. Waddel, Personnel Administration in Higher Education (California: Jossey Bass Inc., 1981), hlm. 189. 
f. Sering berkomunikasi dengan rekan kerja. $^{43}$

Keragaman usaha yang dilakukan untuk mengembangkan pengetahuan guru di atas diharapkan dapat meningkatkan kemampuan guru dalam melakukan tugas. Jika sebelumnya guru hanya mampu bekerja secara efektif selama tujuh jam, maka setelah pendidikan dan latihan (diklat) ia mampu senantiasa bekerja efektif. Contoh lainnya, yaitu bila guru dulunya hanya bisa menerapkan dua metode dalam mengajar maka setelah pendidikan dan latihan (diklat) pemakaian metode lebih bervariasi.

Dalam hal pengembangan keterampilan dan sikap guru melalui pendidikan dan latihan (diklat), biasanya usaha tersebut dilaksanakan dengan menerapkan teknikteknik pengembangan. Ada beberapa teknik yang digunakan dalam menjalankan pengembangan sumber daya manusia. Teknik-teknik ini dirancang untuk dapat meningkatkan prestasi kerja, mengurangi absensi, dan perputaran, serta memperbaiki kepuasan kerja. Ada dua katergori pokok program pengembangan:

\section{a. Metode Praktis}

Metode pelatihan di tempat kerja (on the job training) paling banyak dipakai dalam usaha pengembangan pegawai. Hal ini didasarkan pada anggapan bahwa sebagian besar pekerjaan dapat dipelajari dalam jangka waktu yang relatif singkat. Metode ini mempunyai kelebihan, karena memberi motivasi besar kepada penatar untuk belajar karena situasi kelas pelatihan itu

43 Gouzali Saydam, Manajemen Sumber Daya Manusia, Jilid II, Cet. Pertama (Jakarta: Gunung Agung, 1996), hlm. 63. tidak berlangsung dalam situasi yang artifisial. Pelatihan dalam tugas dilakukan untuk guru yang sedang bertugas atau berdinas dalam suatu lembaga pendidikan. Sifatnya menambah ilmu dan meningkatkan keterampilan pada guru sehingga mereka dapat melaksanakan tugas secara profesional.

Teknik-teknik yang dipakai dalam on the job training adalah sebagai berikut:

1) Rotasi jabatan; agar guru punya pengetahuan pada bidang-bidang yang lain, selain bidang yang ia geluti.

2) Latihan instruksi pekerjaan; petunjuk-petunjuk yang diberikan secara langsung pada pekerjaan sehingga guru mengetahui cara kerjanya.

3) Magang; proses belajar dari seseorang atau beberapa yang telah memiliki kemampuan dan pengalaman.

4) Coaching; pemberian bimbingan dan arahan oleh atasan secara langsung.

5) Penugasan sementara, penempatan guru sebagai pendidik pada suatu posisi manajerial atau sebagai anggota suatu kepanitiaan untuk jangka waktu yang ditetapkan. ${ }^{44}$

\section{b. Metode-Metode Simulasi}

Metode ini merupakan pelatihan di luar tempat kerja yang mengambil lokasi di luar lingkungan kerja, tetapi dengan usaha simulasi kondisi tempat kerja yang sebenarnya.

44 Handoko, Manajemen, hlm. 112-13. 
1) Metode studi kasus; deskripsi tertulis tentang situasi pengambilan keputusan nyata disediakan, dengan metode ini diharapkan peserta dapat mengembangkan keterampilan pengambilan keputusan.

2) Role Playing, peserta ditugaskan untuk memainkan peran tertentu dan diminta untuk menanggapi peran peserta lain yang berbeda.

3) Business game; simulasi pengambilan keputusan skala kecil yang dibuat sesuai dengan situasi kehidupan bisnis nyata.

4) Vestibule training; di sini guru dilatih menggunakan peralatan yang sebenarnya dan pengaturan yang realistik, tetapi di ruang yang berbeda dari tempat merka bekerja. Tujuannya adalah menghindari tekanan yang terjadi di tempat kerja yang mungkin mempengaruhi proses belajar. Training ini dilaksanan oleh pelatih khusus dengan menggunakan area yang terpisah dengan berbagai jenis peralatan yang sama dengan pekerjaan sebenarnya.

5) Laboratory training; latihan kelompok yang digunakan untuk mengembangkan ketrampilanketrampilan antar pribadi. ${ }^{45}$

Pelatihan di luar tempat kerja mungkin difokuskan di ruang kelas, dengan seminar, pengajar, dan film, atau menggunakan instruksi dengan bantuan komputer yang dapat mengurangi waktu yang diperlukan untuk pelatihan dan

45 Handoko, Manajemen, hlm. 113-115. menyediakan bantuan lebih besar bagi masing-masing peserta.

Namun metode-metode dan teknikteknik pengembangan di atas tidak akan dapat berjalan secara efektif dan efisien tanpa memperhatikan prinsip-prinsip pengembangan. Beberapa prinsip yang perlu diperhatikan dalam menjalankan kegiatan pengembangan adalah sebagai berikut:

a. Motivasi

b. Laporan kemajuan

c. Reinforcement

d. Praktek

e. Perbedaan individual. ${ }^{46}$

Motivasi dijadikan prinsip yang pertama, karena berdasarkan motivasi maka seseorang bisa terdorong untuk melakukan sesuatu. Bila motivasinya tinggi, maka secara otomatis ia dapat mempelajari keterampilan atau pengetahuan baru yang ditawarkan kepadanya dengan cepat. Sedangkan laporan kemajuan diperlukan untuk melihat seberapa jauh seorang guru memahami pengetahuan yang baru didapatnya. Reinforcement perlu dilakukan untuk mendorong guru agar lebih giat belajar, sehingga motivasinya akan bertambah karena diperkuat lagi dengan pemberian hadiah ataupun hukuman yang semuanya itu ditujukan untuk kemajuan para guru dalam bekerja.

Prinsip selanjutnya yaitu mempraktekkan ilmu yang didapat dari pendidikan dan latihan (diklat) juga tak kalah pentingnya, sebisa mungkin guru segera mempratekkan ketrampilan yang didapatnya ke dalam suasana kerja yang sesungguhnya. Dalam pengembangan, perbedaan individual juga

46 Ranupandojo dan Husnan, Manajemen, hlm. 82. 
patut dipertimbangkan, karena pendidikan dan latihan (diklat) akan berjalan lebih efektif bila kecepatan dan kerumitan suatu keterampilan disesuaikan dengan kemampuan dan kebutuhan masing-masing peserta.

Pelaksanaan upaya pengembangan dengan berbagai metode, teknik dan prinsipnya, merupakan suatu hal yang mutlak diadakan agar hasil yang dicapai lebih optimal. Seiring dengan perkembangan zaman tentunya lembaga pendidikan akan menemui berbagai macam perubahan, baik itu pengembangan struktur organisasi lembaga pendidikan, pengembangan penggunaan teknologi baru dan struktur kerja. Maka perubahan dan kemajuan yang terjadi tidak hanya dijadikan sebagai tolak ukur tetapi juga sebagai tantangan bagi pihak lembaga pendidikan, apakah mereka telah siap menghadapi perubahan tersebut. Tentunya melalui pendidikan dan pelatihan bagi para guru, sehingga siap menghadapi berbagai perubahan dan kemajuan yang terus terjadi.

Pentingnya pelaksanaan pendidikan dan latihan (diklat) bagi guru adalah karena kegiatan tersebut juga berarti mengembangkan martabat serta kualitas dirinya sebagai manusia dan peningkatan martabat serta kualitas itu tidak lain dengan memberikan kemampuan kepada guru untuk dapat memilih dan memperkaya horizon pilihannya. Peningkatan kualitas berarti peningkatan atas rangkaian pilihannya seperti terhadap kesehatan serta umur yang panjang, memperoleh pendidikan yang cukup serta standar hidup yang memadai, serta kemerdekaan yang bertanggungjawab. Dengan demikian peningkatan martabat bukan hanya untuk memenuhi kebutuhan dasar saja, tetapi juga untuk pengembangan guru sebagai peserta yang aktif dalam proses pembangunan. ${ }^{47}$

Pendidikan dan latihan sangat dibutuhkan terutama bagi guru sebagai tenaga profesional, dengan tugas yang bersifat spesialis, harus mendapat kesempatan berpromosi, mendapat insentif untuk meningkatkan kontribusi, dan profesinya mendapat pengakuan, baik daripihak anggota organisasi maupun luar organisasi. Mereka ini dipersyaratkan memiliki satu bidang keahlian, yang diperoleh dari belajar secara formal, menekankan layanan dalam bekerja bukan keuntungan materi, memiliki kode etik, sebagai anggota organisasi profesi, dan mendapat izin untuk melaksanakan tugas. $^{48}$

\section{G. Jenis pelatihan dan pengembangan}

Terdapat banyak pendekatan untuk pelatihan. Menurut Simamora. Ada lima jenis pelatihan yang dapat diselenggarakan:

1. Pelatihan keahlian

Pelatihan keahlian (Skill Training) merupakan pelatihan yang sering dijumpai dalam organisasi. Program pelatihannya relatif sederhana: kebutuhan atau kekurangan diidentifikasi melalui penilaian yang jeli. Kriteria penilaian efektifitas pelatihan juga berdarkan pada sasaran yang diidentifikasikan dalam tahap penilaian.

47 H.A.R., Tilaar, Manajemen Pendidikan Nasional, Kajian Pendidikan Masa Depan, (Bandung: Remaja Rosdakarya, 1994), hlm. 106-107.

48 Made Pidarta, Manajemen Personalia, Cet. Pertama (Jakarta: Bina Aksara, 1988), hlm. 130. 


\section{Pelatihan ulang.}

Pelatihan ulang (retraining) adalah subset pelatihan keahlian. Pelatihan ulang berupaya memberikan para karyawan keahlian-keahlian yang mereka butuhkan untuk menghadapi tuntutan kerja yang berubah-ubah. Seperti tenaga kerja instansi pendidikan yang biasanya bekerja menggunakan mesin ketik manual, sehingga harus dilatih dengan mesin komputer atau akses internet.

\section{Pelatihan lintas fungsional}

Pelatihan lintas fungsional (Gros Fungsional traing) melibatkan pelatihan karyawan untuk melakukan aktivitas kerja dalam bidang lainnya selain pekerjaan yang ditugaskan.

\section{Pelatihan tim}

Pelatihan tim merupakan bekerjasama terdiri dari sekelompok individu untuk menyelesaikan pekedaan demi tujuan bersama dalam sebuah tim kerja.

5. Pelatihan. kreatifitas

Pelatihan kreatifitas (Creativitas Training) berdasarkan kepada asumsi bahwa kreatifitas dapat dipelajari. Maksudnya tenaga kerja diberikan peluang untuk mengeluarkan gagasan sebebas mungkin, yang berdasar kepada penilaian rasional dan biaya dan kelayakan. $^{49}$

\section{H. Penutup}

Pada hakekatnya pengembangan sumber daya manusia diarahkan untuk mengantisipasi perubahan-perubahan yang terjadi ataupun untuk mengantisipasi penurunan kemampuan dan ke-usangan keahlian yang terjadi di sekitar organisasi. Pelatihan dan pengembangan merupakan salah satu solusi terhadap antisipasi organisasi atau lembaga dan instansi yang disebabkan oleh penurunan kemampuan dan keusangan keahlian yang dimiliki tenaga kerja.

Pelatihan merupakan penciptaan suatu lingkungan dimana kalangan tenaga kerja dapat memperoleh dan mempelajari sikap, kemampuan, keahlian pengetahuan perilaku spesifik yang berkaitan dengan pekerjaan. Pelatihan merupakan serangkaian aktivitas yang dirancang untuk meningkatkan keahlian, pengetahuan, pengalaman, ataupun perubahan sikap seseorang.

Pengembangan adalah penyiapan individu untuk mengembangkan tanggung jawab yang berbeda atau lebih tinggi di dalam organisasi. Pengembangan biasanya berkaitan dengan peningkatan kemampuan intelektual atau emosional yang diperlukan untuk melaksanakan pekerjaan yang lebih baik.

Pelatihan lebih terarah peningkatan kemampuan dan keahlian sumber daya manusia yang berkaitan dengan jabatan atau fungsi yang menjadi tanggung jawab individu yang bersangkutan saat ini (curren Job oriented). Sasaran yang ingin dicapai dari suatu program pelatihan adalah peningkatan kerja individu dalam jabatan atau fungsi saat ini.

Pengembangan lebih cenderung bersifat formal, menyangkut antisipasi kemampuan dan keahlian individu yang harus dipersiapkan bagi kepentingan jabatan yang akan datang.

\footnotetext{
49 Hendri Simamora, Manajemen Sumber Daya, hlm. 273.
} 


\section{Daftar Pustaka}

Armstrong, 1991, M, Personnel Management Practice, Fourth Edition, London: Kogan Page limited.

Dessler, Gary, 1995, Penerjemah: Agus Dharma, Manajemen Personalia, Jakarta: Penerbit Erlangga.

Fatah, Nanang, 2005, Landasan Manajemen Pendidikan, Bandung: Rosda Karya

Hafidhuddin, Didin dan Hendri Tanjung, 2003, Manajemen Syariah dalam Praktik, Jakarta: GIP.

Handoko, Hani T, 1993, Manajemen Personalia dan Sumber Daya Manusia, Edisi 2, BPFE, Yogyakarta: Pustaka Pelajar.

Hasibuan, 1994, Manajemen Sumber Daya Manusia, Jakarta: Haji Masagung.

Muhaimin, et. al, 2010, Manajemen Pendidikan, Jakarta: Kencana.

Mujahid, 2003, Manajemen Lembaga pendidikan Mandiri, Jakarta: Puslitbang.

Nangoi, 1996, Ronald, Pengembangan Produksi Dan Sumber Daya Manusia, Cet. Kedua, Jakarta: Rineka Cipta.

Nasir, Usman, 2012, Manajemen Peningkatan Mutu Kinerja Guru, Konsep, Teori dan Model, Bandung: Citapustaka Media Perintis.

Nitisemito, S.A., 1994, Manajemen Personalia, Edisi Delapan, Jakarta: Penerbit Ghalia Indonesia.
Pidarta, Made, 1988, Manajemen Personalia, Cet. Pertama, Jakarta: Bina Aksara.

Ranupandojo, Heidjrachman dan Suad Husnan, 1986, Manajemen Personalia, Edisi Ketiga, Yogyakarta: Pelajar.

Robert, Mathius L, Jackson. H John, Human Resource Management, Manajemen Sumber Daya Manusia terj. Diana Angelica, Jakarta: Salemba Empat, 2004.

Sabardi, Agus, 2008, Manajemen Pengantar, Yogyakarta: STIM YKPN.

Saydam, Gouzali, 1996, Manajemen Sumber Daya Manusia, Jilid II, Cet. Pertama, Jakarta: Gunung Agung.

Siagian, Sondang, 1992, Fungsi-Fungsi Manajerial, Jakarta: Bumi Aksara.

Simamora, H, 1997, Manajemen Sumber Daya Manusia, Edisi ke-2, Yogyakarta: Penerbit Sekolah Tinggi Ilmu Ekonomi, YKPN.

T. Ray Fortunato dan Geneva D.Waddel, 1981, Personnel Administration in Higher Education, California: Jossey Bass Inc.

Taufik,Rahman,2009, ManajemenSumber

Daya Manusia, Bandung: Cita pustaka. Media Perintis.

Terry R, George, 2001, Dasar-Dasar Manajemen, Jakarta: Bumi Aksara.

Tilaar, H.A.R, 1994, Manajemen Pendidikan Nasional, Kajian Pendidikan Masa Depan, Bandung: Remaja Rosdakarya.

Yusanto et. al., Muhammad Ismail, 2002, Pengantar Manajemen Syariat, Jakarta: Khairul Bayan. 
Drs. Eris Yustiono, M.Sc., Pengembangan SDM (Bagian Pertama), lihat http://www.stialanbandung.ac.id/i ndex.php?option $=$ com_content $\& v$ iew $=$ article $\& i d=389$ :

pengembangan-sdm-bagianpertama\& catid=12:artikel\&Itemid $=85$ 